Journal of Engineering and Applied Sciences 15 (6): 1496-1501, 2020

ISSN: 1816-949X

(C) Medwell Journals, 2020

\title{
Experimental Study on Bearing Capacity of Laterite Soil Stabilization using Zeolite Activated by Waterglass and Geogrid Reinforcement as Base Layer
}

\author{
Marthen M. Tangkeallo, Lawalenna Samang, Achmad Bakri Muhiddin and A.R. Djamaluddin \\ Department of Civil Engineering, Faculty of Engineering, University of Hasanuddin, Gowa, \\ South Sulawesi Province, Indonesia
}

\begin{abstract}
Indonesia is a country with a large amount of laterite soil and zeolite which could be found in an abundant amount in North Toraja. Zeolite is widely used for industrial purposes. Its pozzolanic behavior could also be used as soil stabilizing material. In this research, laterite soil was stabilized using varied refined zeolite percentage of 4, 8, 12, 16 and 20\% activated by using waterglass with 2, 4 and $6 \%$ of soildry weight which then applied in road foundation layer model. California bearing ratio test results of the mixture increased significantly. CBR value increases corresponding with increasing zeolite and waterglass percentage and with increasing curing time. The highest CBR value obtained was $70.44 \%$ achieved by adding $20 \%$ zeolite and $6 \%$ waterglass with 28 days of curing time. Compared to the untreated soil CBR value of $18.70 \%$, the CBR value increased by $376 \%$. As in the model test, the value of modulus of subgrade reaction of stabilized laterite soil was $636.94 \mathrm{kNm}^{-2}$ per mm and by using geogrid as reinforcement, it increased by $150 \%$ and reach a value of $955.41 \mathrm{kNm}^{-2}$ per $\mathrm{mm}$. This result showed that laterite soil stabilization using zeolite activated by waterglass could be properly used as a road foundation.
\end{abstract}

Key words: California Bearing Ratio (CBR), laterite soil, base layer, subgrade, waterglass

\section{INTRODUCTION}

Construction of road embankment over a soft soil poses challenging problems. Generally, soft clay is not strong enough for supporting embankment stability (Harianto et al., 2016). Materials for road foundation in certain areas is often a problem, since, it is difficult to obtain, expensive and a limited number of sources that meet specification (Saing et al., 2017). Soil improvements are commonly done in construction work to increase the bearing capacity of the soil, so that, it can withstand the load of structure.

Indonesia as an archipelago country has many kinds of soil. One of them was laterite soil which estimated about 8085 million hectares spread in Sumatera, Kalimantan, Sulawesi, Irian Jaya and Java island. Besides laterite soil, Indonesia also has an abundant amount of lime. Mostly in areas rich in limes are rich in the zeolite. Zeolite in Indonesia dominated by mordenite and clinoptilolite minerals. Mordenite is a zeolite mineral with the chemical formula $\left(\mathrm{Ca}, \mathrm{Na}_{2}, \mathrm{~K}_{2}\right) \mathrm{Al}_{2} \mathrm{Si}_{10} \mathrm{O}_{24} \cdot 7 \mathrm{H}_{2} \mathrm{O}$ and it is one of the six most abundant zeolites and is used commercially. Clinoptilolite is a natural zeolite composed of a microporous arrangement of silica and alumina tetrahedra. Its complex compound is (Na, K, Ca $)_{2}-3$ $\mathrm{Al}_{3}(\mathrm{Al}, \mathrm{Si})_{2} \mathrm{Si}_{13} \mathrm{O}_{36} \cdot 12 \mathrm{H}_{2} \mathrm{O}$. Recently, zeolites are mostly used for industrial purposes.

North Toraja regency has about 168 million tons of zeolite, spread in an area of $360000 \mathrm{~m}^{2}$ and also has a huge amount of laterite soil. The regency is considered as one of the Indonesian regions with difficult access to material for road construction. This condition becomes the background for this research. The potential zeolite was used as stabilizing material for laterite soil. In order to increase its strength as a baselayer in the road foundation, a liquid sodium silica called waterglass is used as an activating agent.

Composition resulted in the highest CBR value then applied to the road foundation model that consists of 3 layers. The subgrade and subbase layer using conventional materials usually used in Indonesia as a foundation layer. The model tests are divided into 2 conditions. One with base layer reinforced by geogrid and the other one without geogrid. The load is then applied to the two models to obtain the modulus values for comparison.

Literature review: In remote areas, most roads still use pavements that are very sensitive to climate change, especially, those using clay pavements with high plasticity. In addition, to the issue of cost, the difficulty of obtaining a proper source of the material is another problem that has led to soaring prices for materials.

Laterites are soil types rich in iron and aluminum that are formed in tropical areas. Most laterites are rusty-red because of the presence of iron oxides. They were formed by intensive and long-lasting weathering of the underlying parent rock. Tropical weathering (laterization) is a

Corresponding Author: Marthen M. Tangkeallo, Department of Civil Engineering, Faculty of Engineering, University of Hasanuddin, Gowa, South Sulawesi Province, Indonesia 
prolonged process of chemical weathering that produces variety in thicknesses, grades, Chemistry and ore mineralogy of the resulting soils. The initial products of weathering are essentially kaolinite rocks called saprolites (Dalvi et al., 2004).

Lateritic soils are products of tropical weathering with red, reddish-brown or dark brown color with or without nodules or concretions and generally (but not exclusively) found below hardened ferruginous crusts (Ola, 1983). Laterite formation factors include climate (precipitation, leaching, capillary rise and temperature), topography (drainage), vegetation, parentrock (iron-rich rocks) and time of these primary factors. However, the climate is considered to be th emost important factor (Nnochiri and Aderinlewo, 2016).

The need to improve the strength and durability of lateritic soil in recent times has be come imperative, this has geared researchers towards using stabilizing materials that can be sourced locally at a very low cost (Bello et al., 2015).

The positive effect of zeolite on cemented sand strength requires the curing time to be long enough due to a pozzolanic reaction. The pozzolanic activity of zeolites with cement depends on their chemical and mineralogical compositions (Mola-Abasi and Shooshpasha, 2016).

Similar to other pozzolanic materials, zeolite substitution can improve the strength of cement by pozzolanic reaction with $\mathrm{Ca}(\mathrm{OH})_{2}$, prevent undesirable expansion due to alkali-aggregate reaction, reduce the porosity of the blended cementpaste and improve the interfacial microstructure properties between the blended cement paste (Feng et al., 1990; Poon et al., 1999; Canpolat et al., 2004).

Natural zeolite contains large quantities of reactive $\mathrm{SiO}_{2}$ and $\mathrm{Al}_{2} \mathrm{O}_{3}$ (Breck, 1974). Similar to other pozzolanic materials such as silica fumes and fly ash, zeolite substitution can improve the strength of concrete by the pozzolanic reaction with $\mathrm{Ca}(\mathrm{OH})_{2}$. In general, natural zeolite, like other pozzolanic materials, contributes to the strength of concrete better than the strength of cement
(Negis, 1999). Natural zeolite also prevents undesirable expansion due to alkali-aggregate reaction (Canpolat et al., 2004).

The sodium silicate can reduce the plasticity and slightly increased the Unconfined Compression Strength (UCS) of the soils, also the UCS increased with the duration of curing time. It can be concluded that the stabilization using sodium silicate can be used as an alternative and economic method in civil engineering projects (Breck, 1974).

\section{MATERIALS AND METHODS}

In order to classify the material used in this experimental study, a laboratory investigation program was carried out to evaluate the basic properties and mechanical properties of the laterite soil.

The laterite soil was sampled from North Torajaat coordinate -2.946913 S and 119.907934 E while the natural zeolite sampled at the coordinate $-2.840901 \mathrm{~S}$ and 119.939216 E. Both laterite soil and zeolite are used locally in North Toraja regency as foundation layers (Fig. 1 and 2).

The natural zeolite used in this study was refined and filtered using sieve No. 40. These refined zeolites were then mixed with laterite soil as shown in Table 1.

Waterglass was added as a cementitious agent. The optimum composition then determined by obtaining the highest CBR (ASTM D1883) value achieved. After obtaining the optimum composition, it then applied to a road foundation layer model and placedit at the baselayer. The model was tested in 2 conditions, i.e., using geogrid as reinforcement and without geogrid. Composition of zeolite, waterglass and curing time are presented in Table 1.

The CBR samples are tested in certain curing times to let the pozzolanic reaction between laterite soil, zeolite and waterglass stable. The results are then compared to untreated laterite soil to identify the improvement of CBR value.

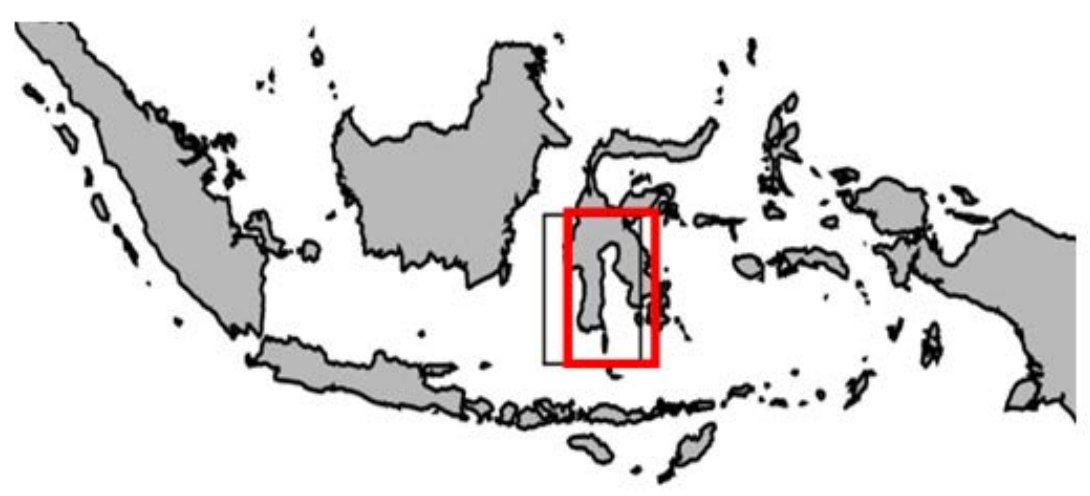

Fig. 1: North Toraja relative to Indonesia perspective 


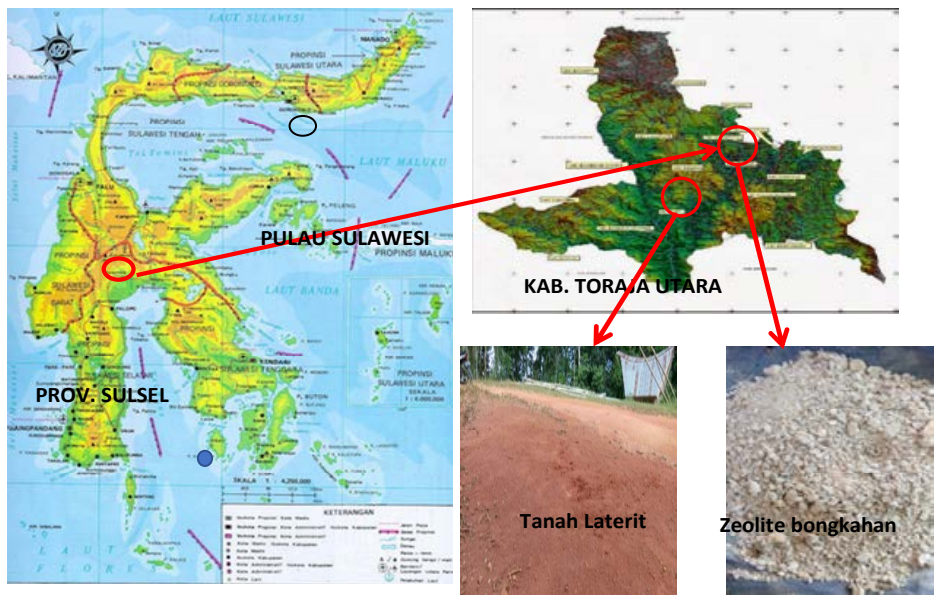

Fig. 2: North Toraja relative to Sulawesi island perspective

Table 1: Mix design of laterite soil stabilization

\begin{tabular}{lcllll}
\hline Composition (\%) & \multicolumn{4}{l}{ Curing time (days) } & \\
Zeolite & Waterglass & 0 & 7 & 14 & 28 \\
\hline 0 & 0 & 3 & - & - & - \\
4 & 2 & 3 & 3 & 3 & 3 \\
& 4 & 3 & 3 & 3 & 3 \\
& 6 & 3 & 3 & 3 & 3 \\
8 & 2 & 3 & 3 & 3 & 3 \\
& 4 & 3 & 3 & 3 & 3 \\
& 6 & 3 & 3 & 3 & 3 \\
12 & 2 & 3 & 3 & 3 & 3 \\
& 4 & 3 & 3 & 3 & 3 \\
& 6 & 3 & 3 & 3 & 3 \\
16 & 2 & 3 & 3 & 3 & 3 \\
& 4 & 3 & 3 & 3 & 3 \\
20 & 6 & 3 & 3 & 3 & 3 \\
& 2 & 3 & 3 & 3 & 3 \\
& 4 & 3 & 3 & 3 & 3 \\
& 6 & 3 & 3 & 3 & 3 \\
\hline
\end{tabular}

\section{RESULTS AND DISCUSSION}

The test is conducted in Soil Mechanics Laboratory at Hasanuddin University, Gowa, South Sulawesi, Indonesia. The tests carried out following ASTM standards. Soil classification based on AASHTO and USCS standards. In this research, the curing time varied from 0-28 days. This was meant to observe the pozzolanic reaction rate at a certain period. Result of basic properties and engineering properties of laterite soil are shown in Table 2.

According to laboratory analyzes, the plastic limit value obtained was $47.35 \%$ and the plasticity index was $12.40 \%$. Based on plastic limit values and the plasticity index, the soil type is classified as MH (high plasticity silt) which corresponds to silty soils with high plasticity. Soil grains are mainly silt fraction of $58.10 \%$ and clay of $16.50 \%$. By considering properties result, the laterite soil used in this research was classified as silty soil.
Table 2: Recapitulation of basic properties and engineering properties of laterite soil

\begin{tabular}{|c|c|c|c|}
\hline \multirow[b]{2}{*}{ Soil characteristic } & \multicolumn{2}{|c|}{ Test results } & \multirow[b]{2}{*}{ Testing method } \\
\hline & Unit & Values & \\
\hline \multicolumn{4}{|l|}{ Basic properties } \\
\hline Specific Gravity (Gs) & - & 2.68 & D-854 \\
\hline Initial water content (w) & $\%$ & 32.42 & D-2216 \\
\hline \multicolumn{4}{|l|}{ Sieve analysis } \\
\hline Gravel & $\%$ & 15.20 & D-6913 \\
\hline Sand & $\%$ & 10.20 & \\
\hline Silt & $\%$ & 58.10 & \\
\hline Clay & $\%$ & 16.50 & \\
\hline \multicolumn{4}{|l|}{ Atterberg limits } \\
\hline Liquid Limit (LL) & $\%$ & 59.75 & D-4318 \\
\hline Plastic Limit (PL) & $\%$ & 47.35 & \\
\hline Plasticity Index (PI) & $\%$ & 12.40 & \\
\hline \multicolumn{4}{|l|}{ Engineering Properties } \\
\hline \multicolumn{4}{|l|}{ Standard proctor } \\
\hline Max dry density ( $\gamma d$ max) & $\%$ & 1.512 & D-698 \\
\hline $\begin{array}{l}\text { Optimum moisture content } \\
\text { (wopt) }\end{array}$ & $\%$ & 25.00 & \\
\hline $\begin{array}{l}\text { Unconfined compressive } \\
\text { strength (qu) }\end{array}$ & $\%$ & 0.998 & D-2166 \\
\hline \multicolumn{3}{|c|}{ California Bearing Ratio (CBR) $(\mathrm{N}=56)$} & D-1883 \\
\hline CBR unsoaked & $\%$ & 18.70 & \\
\hline
\end{tabular}

As shown in Fig. 3 by adding zeolite and waterglass, the CBR values of laterite soil increased significantly. CBR values increase corresponding to increasing zeolite and waterglass percentages. The highest CBR value obtained was $70.44 \%$ achieved by adding $20 \%$ zeolite and $6 \%$ waterglass. Compared to the untreated soil CBR value of $18.70 \%$, the CBR value increased to $376 \%$ of untreated soilvalue. The CBR values of the stabilized laterite soil shown in Table 3.

Based on the CBR test result above (Table 3), the optimum composition could be determined. The CBR value target was $50 \%$ minimum for baselayer according to Indonesian standard (SKBI-2.3.26.1987), technical guidance flexible pavement layer using component analysis method. Several compositions from Table 3 that 


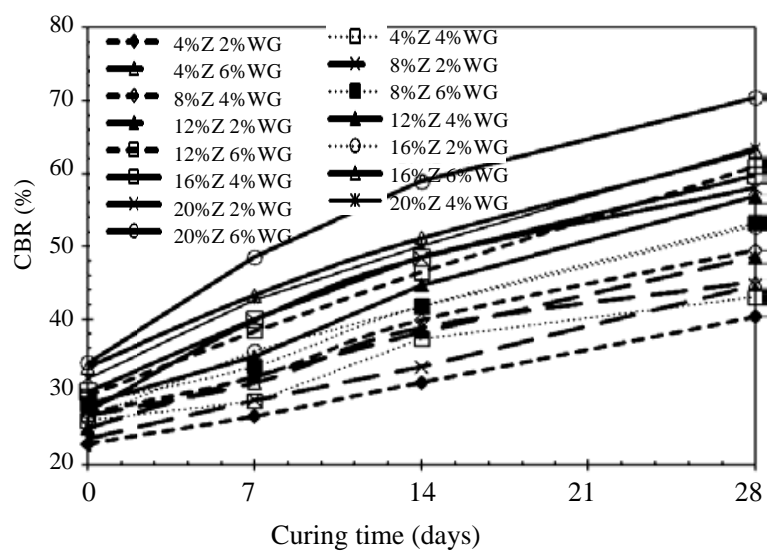

Fig. 3: CBR test result

\begin{tabular}{lcllll}
\multicolumn{2}{l}{ Table 3: CBR test result } \\
\hline & & \multicolumn{5}{l}{ CBR value (\%) (Days) } \\
\cline { 2 - 5 } Zeolite (\%) & Waterglass (\%) & 0 & 7 & 14 & 28 \\
\hline 0 & 0 & 18.7 & - & - & - \\
4 & 2 & 22.93 & 26.68 & 31.32 & 40.32 \\
8 & & 23.68 & 28.93 & 33.42 & 44.66 \\
12 & & 25.03 & 32.22 & 38.22 & 48.56 \\
16 & & 26.53 & 35.67 & 41.81 & 52.76 \\
20 & & 27.43 & 39.87 & 48.41 & 58 \\
4 & 4 & 26.08 & 28.78 & 37.32 & 43.01 \\
8 & & 27.13 & 32.07 & 39.87 & 49.46 \\
12 & & 28.33 & 34.92 & 44.66 & 56.8 \\
16 & & 30.12 & 40.02 & 48.56 & 59.8 \\
20 & 6 & 31.92 & 42.71 & 50.06 & 63.55 \\
4 & & 26.83 & 31.32 & 38.82 & 45.11 \\
8 & & 28.48 & 33.57 & 41.81 & 53.21 \\
12 & & 29.53 & 38.37 & 46.46 & 61 \\
16 & & 33.42 & 43.31 & 51.11 & 63.1 \\
20 & & 34.02 & 48.56 & 58.9 & 70.44 \\
\hline
\end{tabular}

exceed the standard value, however, for model test the composition was chosen was $16 \%$ zeolite and $4 \%$ waterglass with 28 days of curing period with CBR value of $59.8 \%$.

The model test consists of a box with $150 \mathrm{~cm}$ in length and $60 \mathrm{~cm}$ width filled with 3 layers ofsoil with different CBR values (Fig. 4). All 3 layers were compacted using the optimum water content of standard proctor with the same density. The subgrade and subbase layer using conventional material used in Indonesia. For the subgrade layer, alluvial soil with $8.76 \%$ CBR value (standard minimal 6\%) was used with $50 \mathrm{~cm}$ thickness. The subbase layer was gravelly, sand with a CBR value of 20.07\% (standard minimal 20\%) with $15 \mathrm{~cm}$ thick. The base layer used stabilized soil compacted with $15 \mathrm{~cm}$ thick. The objective of the model test was to obtain the modulus of subgrade reaction by plotting settlement and the corresponding load.

Geogrid was applied in order to increase the load capacity, assuming that it would bear a heavier vehicle than the non-geogrid one and also in case of a higher safety factor. The results of the model test are shown in Fig. 5.

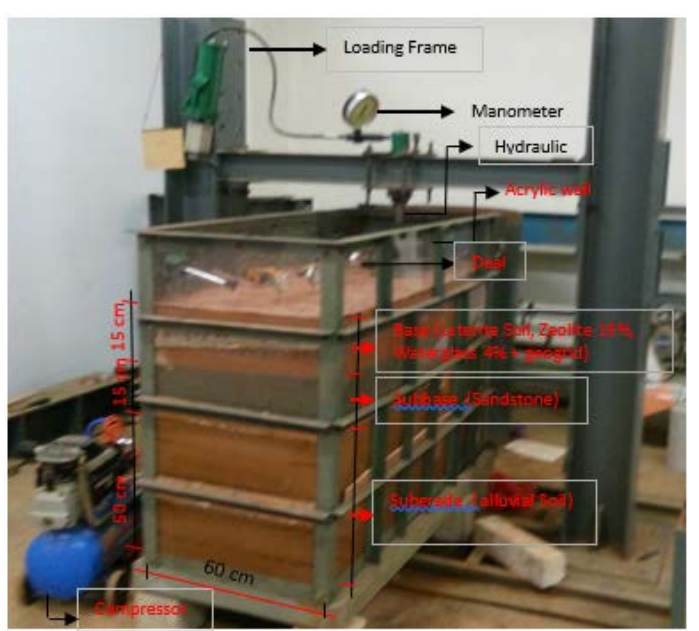

Fig. 4: The arrangement of the physical model of road base layer test

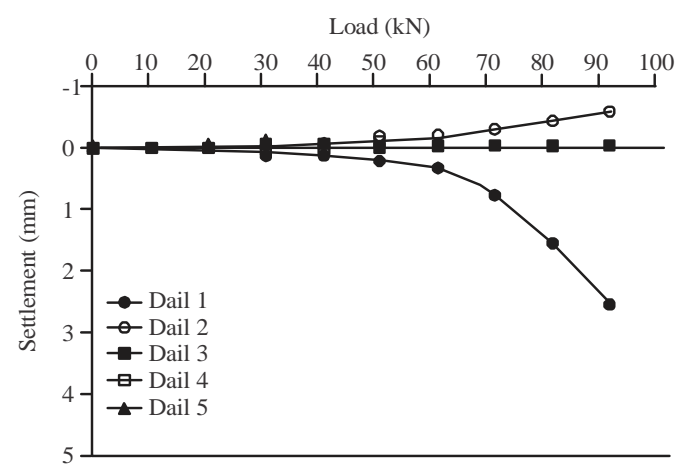

Fig. 5: Load-settlement relation on base layer model with geogrid reinforcement

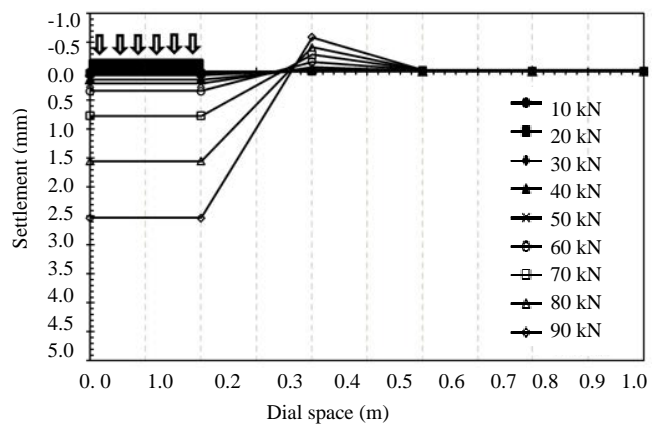

Fig. 6: Deformation behavior per load phase of stabilized laterite soil with geogrid reinforcement

Figure 6 shows that the highest settlement occurred was $2.53 \mathrm{~mm}$ at a load of $90 \mathrm{kN}$. At $20 \mathrm{~cm}$ apart from the load applied, uplifting occurred by $0.59 \mathrm{~mm}$. The modulus of subgradereaction was determined by obtaining the settlement and load as shown in Fig. 6. 


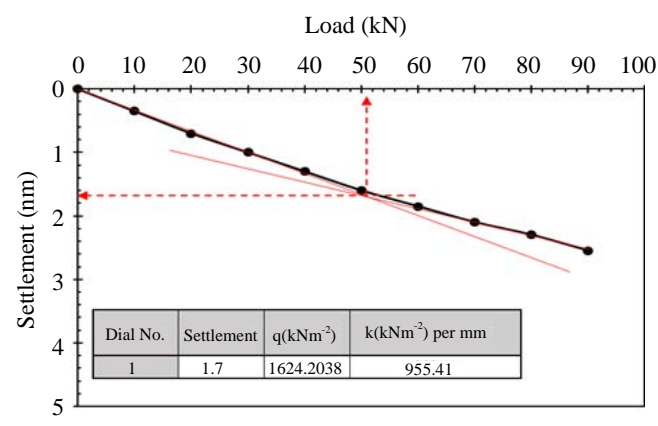

Fig. 7: Modulus value of stabilized laterite soil with geogrid reinforcement

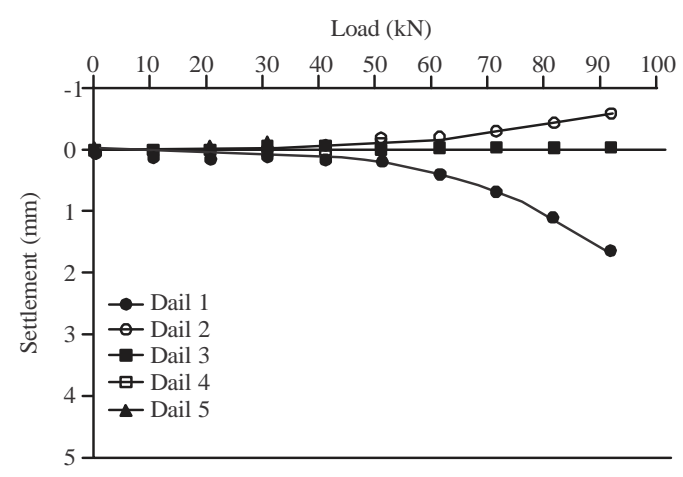

Fig. 8: Load-settlement relation on base layer model non-geogrid

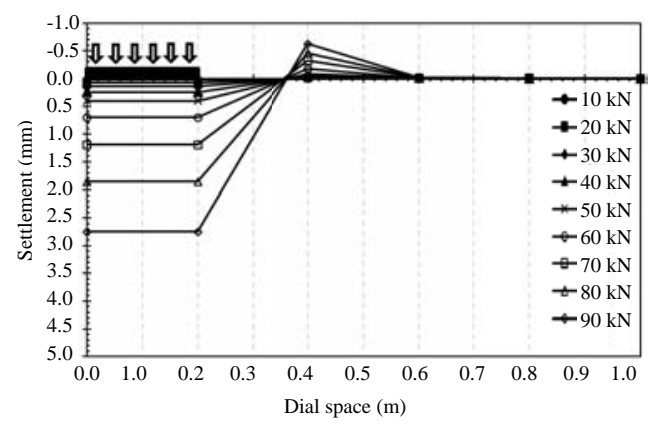

Fig. 9: Deformation behavior per load phase of stabilized laterite soil non-geogrid

In Fig. 7, the settlement was $1.7 \mathrm{~mm}$ corresponding toa load of $51 \mathrm{kN}$ resulting in the modulus of subgrade reaction of $955.41 \mathrm{kNm}^{-2}$ per mm. Without using geogrid as reinforcement, the base layer showed higher settlement at the same load compared to the base layer with geogrid reinforcement. This result shows that geogrid has a function to reduce settlement (Fig. 8).

In Fig. 9 and 10, the settlement was $2 \mathrm{~mm}$ corresponding toa load of $40 \mathrm{kN}$ resulting in the modulus of subgrade reaction of $636.94 \mathrm{kNm}^{-2}$ per mm. From Fig. 11, it is clear that geogrid has a critical function relative to the non-reinforced base layer. The modulus value increases to $150 \%$ of the non-reinforced base layer.

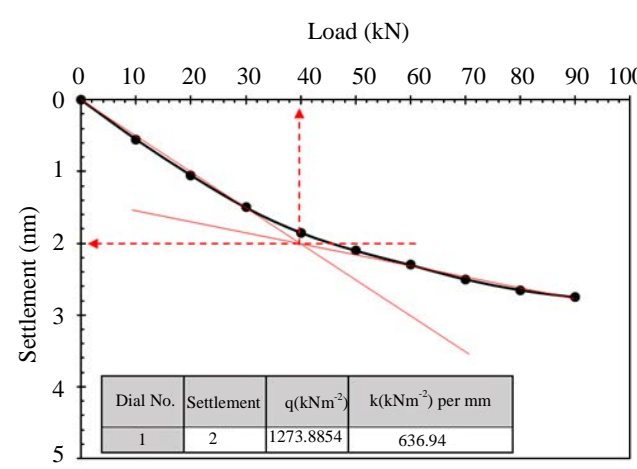

Fig. 10: Modulus value of stabilized laterite soil non-geogrid

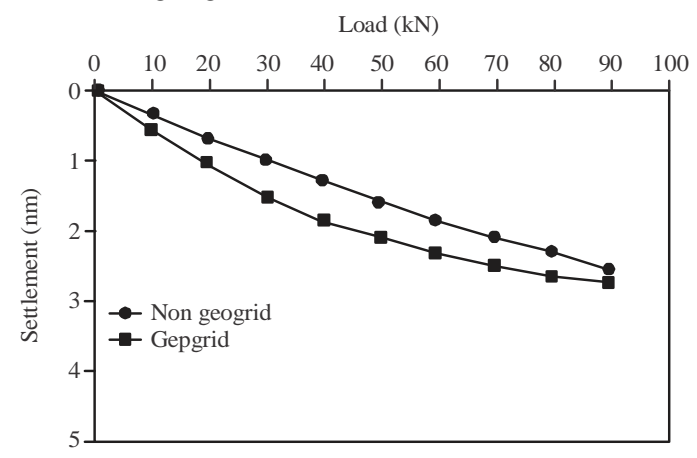

Fig. 11: Load-settlement comparation of geogridreinforced base and non-geogrid

From the above result, it is shown that laterite soil stabilization using zeolite activated by waterglass increasessoil capacity for application as a base layer. There might be a chance of obtaining better value by using other compositions whichresulted in higher CBR value. It is hoped that this result could be a reference for areas similar to North Toraja with an abundant amount of local laterite soil and zeolite. The material has been proven able to be used as construction material, especially, road construction which will lead to better development.

\section{CONCLUSION}

Zeolite and waterglass have been proven to be a good combination as stabilizers and activators for laterite soil. The bearing capacity of the laterite soil increased to $376 \%$ of untreated soil value. The modulus of subgrade reaction of stabilized laterite soil was $636.94 \mathrm{kNm}^{-2}$ per $\mathrm{mm}$ and by using geogrid as reinforcement, it increased to $150 \%$ of untreated soil and reached a value of $955.41 \mathrm{kNm}^{-2}$ per mm. This result showed that laterite soil stabilization using zeolite activated by waterglass could be used as a road foundation. 


\section{ACKNOWLEDGEMENT}

The researchers gratefully acknowledge the financial support from LPDP (Lembaga Pengelola Dana Pendidikan), the Geo-Environmental Laboratory teams of Hasanuddin University and colleagues for their technical support during the experimental works.

\section{REFERENCES}

Bello, A.A., J.A. Ige and H. Ayodele, 2015. Stabilization of lateritic soil with cassava peels ash. Br. J. Applied Sci. Technol., 7: 642-650.

Breck, D.W., 1974. Zeolite Molecular Sieves: Structure, Chemistry and Use. Wiley Interscience, New York, USA., ISBN-13: 978-0471099857, Pages: 771.

Canpolat, F., K. Yilmaz, M.M. KÅse, M. Sumer and M.A. Yurdusev, 2004. Use of zeolite, coal bottom ash and fly ash as replacement materials in cement production. Cement Concrete Res., 34: 731-736.

Dalvi, A.D., W.G. Bacon and R.C. Osborne, 2004. The past and the future of nickel laterites. Proceedings of the PDAC 2004 International Convention, Trade Show \& Investors Exchange, March 7-10, 2004, The Prospectors and Developers Association of Canada, Toronto, Canada, pp: 1-27.

Feng, N.Q., G.Z. Li and X.W. Zang, 1990. High-strength and flowing concrete with a zeolitic mineral admixture. Cem. Concr. Aggregates, 12: 61-69.
Harianto, T., L. Samang, Y.S. Suheriyatna and Y. Sandyutama, 2016. Field investigation of the performance of soft soil reinforcement with inclined pile. Proceedings of the 5th International Conference On Geotechnical and Geophysical Site Characterisation (ISC'16), September 5-9, 2016, Australian Geomechanics Society, Sydney, Australia, pp: 1349-1352.

Mola-Abasi, H. and I. Shooshpasha, 2016. Influence of zeolite and cement additions on mechanical behavior of sandy soil. J. Rock Mech. Geotech. Eng., 8: 746-752.

Negis, F., 1999. Zeolite based composites in energy storage. Master's Thesis, Izmir Institute of Technology, Urla, Turkey.

Nnochiri, E. and O. Aderinlewo, 2016. Geotechnical properties of lateritic soil stabilized with the ashes of oil palm fronds. Civil Eng. J., Vol. 4, 10.14311/CEJ.20 16.04.0022

Ola, S.A., 1983. Geotechnical Properties and Behaviour of Some Nigerian Lateritic Soils. In: Tropical Soils of Nigeria in Engineering Practice, Rotterdam, A.A. and D.A. Balkema (Eds.). Pascal Press, Leichhardt, Australia, pp: 61-84.

Poon, C.S., L. Lam, S.C. Kou and Z.S. Lin, 1999. A study on the hydration rate of natural zeolite blended cement pastes. Constr. Build Mater., 13: 427-432.

Saing, Z., L. Samang, T. Harianto and J. Patanduk, 2017. Study on characteristic of laterite soil with lime stabilization as a road foundation. Intl. J. Appli. Eng. Res., 12: 4687-4693. 